Journal of Life Economics

Cilt / Volume 6, Say1 / Issue 3, 2019, pp. 297-306

E - ISSN: 2148-4139

URL: http://www.ratingacademy.com.tr/ojs/index.php/jlecon

DOİ: https://doi.org/10.15637/jlecon.6.018

Araştırma Makalesi/Research Article

\title{
ANALYSIS OF THE RELATIONSHIP BETWEEN INFLATION, BUDGET DEFICIT AND MONEY SUPPLY IN TURKEY BY ARDL APPROACH: 1980-2017
}

\author{
Begüm ERDÍL ŞAHİN * \\ * Assist. Prof. Dr., Istanbul Kültür University Faculty of Economics and Administrative Sciences, \\ Department of Economics, TURKEY, E-mail: b.sahin@iku.edu.tr \\ ORCID ID: https://orcid.org/0000-0003-0452-1308
}

Geliş Tarihi: 2 Mayıs 2019; Kabul Tarihi: 29 Haziran 2019

Received: 2 May 2019; Accepted: 29 June 2019

\begin{abstract}
Inflation is considered as a monetary phenomenon and its increase is linked with money supply according to the Monetarist view. In other words, the increase in budget deficits leads to an increase in money supply and as a result, inflation rates rise. Inflation is based on fiscal policies rather than monetary policies according to Price Level Fiscal Theory. Accordingly, increasing budget deficits leads to increases in loans, thus causes interest rates to rise and consequently inflation rises as money supply increases. In this study, the relationship between inflation, budget deficit and money supply in Turkey is analyzed using the ARDL bounds testing approach for the 1980-2017 period. According to the empirical results, there was a positive and significant relationship between inflation and budget deficit both in the long and short term.
\end{abstract}

Keywords: Inflation, Deficit, Money Supply, Turkey, ARDL

Jel Codes: E31, E51, E52

\section{INTRODUCTION}

Emerging countries display the tendency to borrow externally to finance their growing budget deficits. While generating an inflation-raising effect on the economy of a country, external borrowing also leads to a reduction in interest rates and prices by increasing aggregate supply. The impacts of the budget deficits in an inflationist environment will vary according to the way they are financed. If governments finance their budget deficits via bond sales, budget deficits may lead to inflation via increase in monetary growth. In this case, inflation is regarded as a monetary element. In other words, the expansion of money supply with budget deficits is a determining factor in price increases (Kaya and Öz, 2016: 639-640).

It is highlighted that in order to prevent price increases, it is possible to restrict monetary financing of budget deficits by selling public bonds to non-bank sectors and thus to limit the 
impact of budget deficits on money supply via the transfer of assets from the private sector to the public sector. However, it is reported in analyses that regardless of the financing method, the impact of budget deficits may vary depending on the behavior of monetary authorities on money supply. The relationship between budget deficits and monetary growth is tested and the analyses performed on this topic as well as the impact of these variables on inflation is evaluated (Altıntaş et al., 2008:186).

Knowing the factors which lead to inflation is important in the selection of adequate policies in the fight against inflation. Therefore, in order to reduce inflation, it is firstly necessary to prevent budget deficits. Thus, based on the assumption that budget deficits impact inflation in Turkish economy, the relationship between inflation, money supply and budget deficit during the period 1980-2017 are analyzed in this paper. Within this scope, theoretical approaches regarding this topic are first described and empirical studies conducted in this field are included. Section four provides information on the ARDL approach and the relationship between inflation, budget deficits and money supply in Turkey is analyzed via this method.

\section{THEORETICAL APPROACHES}

As high inflation rates generally constitute a serious issue in emerging countries, the relationship especially between budget deficits, increase in money supply and overall price levels is an important subject of study. The assessment of traditional theories demonstrates that importance is placed mostly on financial policies rather than monetary policies in the designation of price levels. It is assumed that inflation is just a monetary phenomenon in these models which are based on quantity theory. On the other hand, it is assumed in traditional models that individuals have rational expectations within the scope of the Ricardian Theory of Equilibrium and therefore it is indicated that the fiscal policy does not have any impact on total demand and thus the overall price levels (Oktayer, 2010:432). Whereas Keynes claims that especially the budget deficits deriving from the increase in public expenditures or decrease in tax revenues raises total demand and thus impacts inflation (Bedir and Dikmen, 2014:1).

Monetarism defends that there is an interrelation between budget deficits, money supply and inflation. According to this approach, inflation is a monetary phenomenon. Therefore, the increases occurring in budget deficits lead to an increase in money supply and to an overall rise in prices via this channel. According to Friedman, inflation is generated so that the public sector achieves certain policy goals such as income generation by the government, prevention of unemployment and increase of production. From this respect, inflation originates from the public fiscal policies implemented by the government (Özmen and Koçak, 2012:4).

Monetary policy implementations began to be questioned among the causes of inflation in 1980s. Sargent and Wallace (1981) defended in their study that the relationship between monetary and fiscal policies is important for achieving price stability (Kaya and Öz, 2016: 641). They reported that opting for borrowing within the scope of the tight fiscal policies implemented for financing budget deficits may give rise to a serious inflationist process in the long term. According to this view entitled "Unpleasant Monetarist Arithmetic", the interest burden arising as a result of the borrowing policy of the government due to budget deficits leads to inflation. Thus, they claim that it is possible for fiscal policies to impact overall price levels (Altıntaş at al., 2008:188).

The views of Sargent and Wallace continued with the fiscal theory of the price level (FTPL) introduced by Leeper (1991), Sims (1994) and Woodford (2001). According to the fiscal policy of the price level, fiscal deficits and public debt stocks determine the overall price level in the long term. In other words, the amount of money does not impact the overall price level. Therefore, it is claimed that fiscal policy implementations alone are not sufficient to 
control inflation (Uygur, 2001:11). Furthermore, as the overall price level increases, public debts decrease. In such a circumstance, increasing budget deficits raise total demand with the rise in public expenditures and increase the inflation rate. Thus, the method for financing public expenditures plays a determining role on the inflation rate (Şahin and Karanfil, 2015:99-100).

In the fiscal theory of the price level, inflation results to be a function of the debt stock and not of the amount of money. Therefore, it is necessary to ensure that the monetary policy is under control rather than monetary policy implementations. A central bank which acts independently from fiscal policies may give rise to an increase in the inflation rate. Because, a high inflation rate issue arises as a result of increasing debts and inflation in case of failure to achieve budget discipline. Within this framework, this approach provides a contrary explanation to a Monetarist approach and underlines that inflation is determined by fiscal deficits and the public debt stock brought along with these deficits and not by the amount of money in the long term (Uygur, 2001: 11). Even if the transition channels may vary, it is understood that there is a relationship between budget deficits and money supply and thus inflation (Özmen and Koçak, 2012:4-5).

\section{LITERATURE}

There is no complete consensus on the relationship between these variables in studies examining the relationship between inflation, budget deficits and money supply. However, it is generally stated that the increasing money supply caused by the financing of budget deficits through monetization causes inflation and the inflationary effect of the increasing budget deficits changes according to how the deficits are financed. The following are the studies show the empirical literature conducted on this subject for developed and developing countries.

Chaundhary and Parai (1991) investigated the role of budget deficits in Peru's inflation. They used the rational expectations macro model for Peru for the period 1973:1 to 1988:1 and found out that the budget deficits as well as the rate of growth of money supply do have significant impact on the inflation rates.

Karras (1994) investigated the effects of budget deficits on money growth, inflation, investment and growth using annual data from 32 countries. According to the results, deficits do not produce inflation, are not inflationary and are negatively correlated with the rate of growth of output.

Honroyiannis and Papapetrou (1997) analyzed the direct and indirect effects of budget deficit on inflation in Greece for the period 1957-1993. Results suggests that the indirect effects of budget deficits on inflation exist while the direct effects are not present.

Özgün (2000) has explored the relationship of the budget deficit and the amount of money in circulation on inflation using annual data for Turkey for the 1950-1998 period. According to the results of cointegration analysis, a positive relationship between the variables in the long run was determined. In the causality analysis, it is found that there is a two-way causality relationship between budget deficits and inflation rate.

Tekin-Koru and Özmen (2003) analyzed the long-run relationships between budget deficits, inflation and monetary growth in Turkey and found out that there is no direct relationship between inflation and budget deficits.

Catao and Terrones (2005) modeled inflation as non-linearly related to fiscal deficits through the inflation tax base. Results from 107 countries over 1960-2001 show a strong positive relationship between deficits and inflation among high-inflation and developing country groups, but not among low-inflation advanced economies. 
Altıntaş et al. (2008) have examined the relationship between budget deficit, money supply and inflation via ARDL bounds testing approach for Turkey's economy during 19922006 period. According to the results of the study, a significant and positive relationship was found between monetary growth and inflation in both short and long term. However, no relationship was found between inflation and budget deficit.

Lozano (2008) analyzed the causal longterm relationship between budget deficit, money growth and inflation in Colombia over the last 25 years. Results show that there is a close relationship between inflation and money growth, and money growth and fiscal deficit.

Chimobi and Igwe (2010) analyzed the relationship between inflation, money supply and budget deficit by using the Granger causality test and VAR model for Nigeria between 1970-2005. As a result of the causality test, there was a causality relationship from money supply to budget deficit.

Oktayer (2010) examined the relationship of budget deficit, money supply and inflation in Turkey for the 1987-2009 period by Cointegration analysis. The findings point that the price levels fiscal theory might be vaild in Turkey for a long period.

Habibullah (2011), determined the long-run relationship between budget deficit and inflation in thirteen Asian developing countries by annual data for the period 1950-1999. According to the results, they conculded that budget deficits are inflationary in Asian developing countries.

Özmen and Koçak (2012) examined relations of inflation, budget deficit and money supply using the ARDL bounds testing approach using 1994-2011 period for Turkey's economy. According to the results of the study, no significant relationship was found between inflation and budget deficit, while a significant relationship was found between money supply and inflation.

Bakare, Adesanya and Bolarinwa (2014), investigated the relationship between budget deficit, inflation and money supply with the Johansen cointegration test in their study for the Nigerian economy. Accordingly, a long-term relationship was found and inflation in Nigerian economy depends on budget deficits and monetary expansion.

Hoang (2014) examined the relationship between budget deficit, money supply and inflation by using data from January 1995 to December 2012 and a VAR model for inflation, money growth, budget deficit growth, real GDP growth and interest rate. Overall, results show that money growth has positive effects on inflation while budget deficit growth has no impact on money growth and therefore inflation.

Koyuncu (2014) investigated the effect of money supply and budget deficit on inflation based on the data for period 1987-2013 in Turkey. Accordingly, the two-sided causality from inflation towards the budget deficit has been determined and the budget deficits were highlighted as an important determinant of the inflation process. In addition, a causal relationship has been found from money supply to inflation and it has been stated that a continuous increase in money supply may cause an increase in inflation at the same rate.

Şahin and Karanfil (2015), examined the impact of the money supply, real exchange rate and budget deficit on inflation rate via Johansen cointegration and Granger causality methods in Turkey for the period 1980-2013. According to the results of the analysis, a longterm relationship was found between the variables but there was no direct causality between inflation and money supply.

Kaya and Öz (2016) investigated relationship between monetary growth, inflation and budget deficit in Turkey during the period 1980-2014 via ARDL bounds testing approach. 
According to the findings, there was a significant and positive relationship between inflation and money supply in the long run, but no significant relationship was found between inflation and budget deficit.

\section{ANALYSIS}

\subsection{Data Set and Model}

This paper analyses the relationship between inflation, budget deficit and money supply in Turkey by using the annual data pertaining to the period 1980-2017. Thus, the Consumer Prices Index (CPI) has been used for the inflation rate as a dependent variable while the budget deficit and money supply have been used as independent variables. These data have been obtained from the World Bank and General Directorate of Budget and Financial Control. The budget deficit / GDP value (DEF) has been used as a variable of budget deficit, while broad money, that is the total sum of foreign currencies outside banks, referring to a specific criterion of the amount of money (money supply) in a national economy and obtained from the World Bank, has been used as an indicator of money supply.

The model where the relationship between inflation, money supply and budget deficit has been investigated, is as follows:

$$
C P I_{t}=\alpha_{0}+\alpha_{1} M 2_{t}+\alpha_{2} D E F_{t}+\text { Dummy }+u_{t}
$$

In this model, CPI refers to the consumer prices index, M2 refers to broadly defined monetary aggregates, DEF refers to the ratio of budget deficits to GDP, the Dummy model refers to the dummy variable added for correcting the structural breakage in times of economic crisis and $U_{t}$ refers to the error term coefficient.

\subsection{Methodology}

Cointegration tests are used in the analysis of long-term relationships and the series utilized in the model applied in these tests needs to be stationary. The Johansen Cointegration Test and Granger Cointegration Test frequently used for testing these relationships in literature have been developed for describing the long-term relationships between variables in case they are equally stationary. However, in case the variables used in the model become stationary at different levels, the ARDL (Autoregressive Distributed Lag) model is preferred to solve this issue. The ARDL model is utilized for describing the cointegration relations between series containing different degrees of root causes. Furthermore, as an unrestricted correction model is used in this case, more statistically reliable results are obtained compared to the classical cointegration tests (Akel and Gazel, 2014:30-31).

The ARDL model is used in the bound test of Pesaran, Shin and Smith (2001), thus enabling the analysis of short and long-term relationships without requiring the series in the model to be stationary. This approach allows the conduct of a cointegration analysis regardless of whether the variables are I (0) and I (1). The model firstly established the unrestricted error correction model. Thus, the F test is applied on the lags of dependent and independent variables for the purpose of testing the presence of cointegration relationship. The test statistics included into the model are based on the Wald or F test which express common significance. However, the variables should not have an integration level which is I (2) or higher (Özmen and Koçak, 2012:7).

Lower and upper values are designated in Pesaran, Shin and Smith's paper (2001) depending on whether the variables were fully I(0) and I(1). The null hypothesis, which claims that if the calculated test statistics are above the lower and upper bound values there is no cointegration relationship between series, is being rejected. If the F statistics calculated is below the lower bound, this is regarded as null hypothesis and it is assumed that there is no 
cointegration relationships. If the F statistics calculated are between the lower and upper critical values, no decision may be taken on a long-term relationship (Akel and Gazel, 2014:31).

In the ARDL model, the lag lengths of dependent and independent variables are firstly designated according to Akaike (AIC), Schwartz (SHC) and Hannan Quinn (HQ) information criteria and a suitable model is selected accordingly. Long-term coefficients and standard errors are obtained following the selection of the model. Consequently, the error correction model is established, and the short-term coefficients are interpreted (Abdioğlu and Terzi, 2009:204-205).

\subsection{Unit Root Tests}

It is necessary for the series to be stationary so that significant relationships may be designated between variables in econometric analyses. Granger and Newbold (1974) recorded that a false regression issue may arise in the estimates made by using non-stationary series. If a time series is stationary, its average, variance and common variance in various delays remain the same regardless of when they are measured (Gujarati, 2006: 713).

The variables do not require to be in the ARDL model; however, unit root tests are applied in case the series are stationary at a second order. The order of stationarity of the series in this study have benefited from Augmented Dickey and Fuller (1981) and Philips and Peron (1988) unit root tests. The null hypothesis refers to the presence of unit root, that is nonstationarity of the series while the alternative hypothesis refers to the absence of a unit root, that is the stationarity of the series according to Augmented Dickey-Fuller (ADF) and PhilipsPerron (PP). If $\mathrm{H}_{0}$ cannot be rejected according to the test results, it is decided that the series is not stationary, and the unit root assessment is continued by taking the difference of the series. Tables 1 and 2 provide the results of the unit root tests.

Table 1. ADF Unit Root Test Results

\begin{tabular}{|c|c|c|c|c|}
\hline \multirow{2}{*}{ Variables } & \multicolumn{2}{|c|}{ ADF Level (Fixed) } & \multicolumn{2}{c|}{ ADF First Difference } \\
\cline { 2 - 5 } & Test Statistics & Critical Value (5\%) & Test Statistics & Critical Value (5\%) \\
\hline CPI & -1.861173 & $-2.943427(0.3463)$ & -7.125206 & $-2.945842(0.0000)$ \\
\hline DEF & -1.776595 & $-2.943427(0.3859)$ & -5.574469 & $-2.945842(0.0000)$ \\
\hline M2 & -0.519518 & $-2.945842(0.8757)$ & -8.658830 & $-2.945842(0.0000)$ \\
\hline
\end{tabular}

*Values in parenthesis show probability values.

Table 2. Philips-Perron Unit Root Test Results

\begin{tabular}{|c|c|c|c|c|}
\hline \multirow{2}{*}{ Variables } & \multicolumn{2}{|c|}{ PP Level (Fixed) } & \multicolumn{2}{c|}{ PP First Difference } \\
\cline { 2 - 5 } & Test Statistics & Critical Value (5\%) & Test Statistics & Critical Value (5\%) \\
\hline CPI & -1.944489 & $-2.943427(0.3091)$ & -7.428497 & $-2.945842(0.0000)$ \\
\hline DEF & -1.965340 & $-2.943427(0.3002)$ & -5.574469 & $-2.945842(0.0000)$ \\
\hline M2 & -0.914369 & $-2.943427(0.7725)$ & -18.73272 & $-2.945842(0.0001)$ \\
\hline
\end{tabular}

*Values in parenthesis show probability values.

The assessment of Tables 1 and 2 reveals that the CPI, DEF and M2 series are not equally stationary according to the ADF and PP tests. It is observed as a result of all these unit root tests that all variables to be used in this model are stationary when their first difference is taken.

\subsection{Designation of Adequate Lag Length}

Another key condition for the ARDL model is the designation of the adequate lag length. Thus, the results obtained in line with the AIC criterion are provided in Figure 1. 
Figure 1. Lag Length According to The AIC Criterion

Akaike Information Criteria (top 20 models)

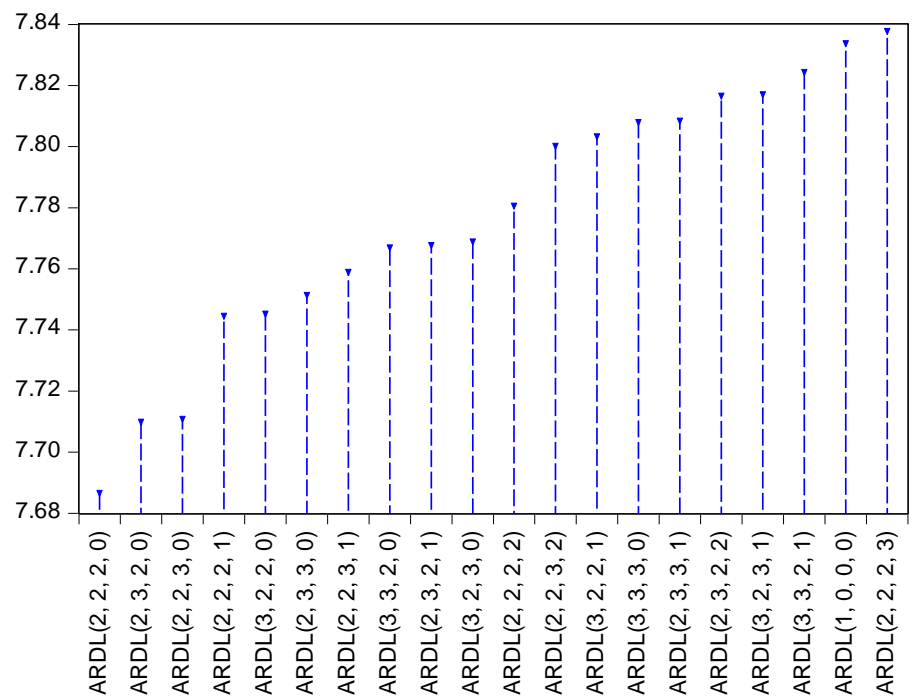

Twenty alternative models designated within the framework of the AIC criterion are for the designation of lag length are provided in Figure 1. Thus, the model with the lowest value $(2,2,2,0)$ has been selected as the most adequate model.

Table 3. Bound Test Results

\begin{tabular}{|c|c|c|c|}
\hline \multirow{2}{*}{$\mathbf{k} *$} & \multirow{2}{*}{ F Statistics } & \multicolumn{2}{|c|}{ Critical Values at a Significance Level of 5\% } \\
\cline { 3 - 4 } & 6.8 & Lower Bound & Upper Bound \\
\hline 3 & 2.79 & 3.67 \\
\hline
\end{tabular}

* Demonstrates the independent variable number in equation $\mathrm{k}$. Critical values have been obtained from

Table CI (iv) in Peseran et al. (2001).

As shown in Table 3, as the calculated F statistics surpasses Pesaran's upper critical value, it has been determined that there is a cointegration relationship between the series. As cointegration relationship has been identified between the series, the estimate will be made with the ARDL (Autoregressive Distribution Lag) model to designate the long and short-term relationships.

Table 4. Estimated Results of the Long-Term Coefficients of ARDL (2, 2, 2, 0) Model

\begin{tabular}{|c|c|c|c|}
\hline Variables & Coefficient & t-Statistics & Probability Value \\
\hline DDEF & 5.671698 & 2.197770 & 0.0374 \\
\hline DM2 & 1.576543 & 1.300918 & 0.2052 \\
\hline Dummy & -19.02910 & -2.684030 & 0.0127 \\
\hline \multicolumn{3}{|c|}{ Diagnostic Test Results } \\
\hline Breusch-Godfrey LM & $0.4251(0.0658)$ \\
\hline Jarque-Bera & $6.2233(0.0545)$ \\
\hline Breusch-Pagan & $0.8561(0,5743)$ \\
\hline
\end{tabular}

Based on the results of Table 4, it is observed that M2, that is the money supply variable is not significant when the coefficient pertaining to the DEF variable is statistically positive and significant in the long term. This result demonstrates that the increase in budget deficits in Turkey has an major impact on inflation.

The evaluation of the diagnostic test results of the model shows that there is no autocorrelation between the series in the model according to the result of the Breusch-Godfrey 
LM test, that the error term is normally distributed according to the results of the Jarque-Bera test and that there is no variable variance issue in the model according to the results of the Breusch-Pagan heteroskedasticity test.

The error correction model based on the ARDL approach is used for designating the short-term relations between the variables. The error correction model demonstrates what part of the imbalance occurring in the short term will be corrected in the long term. In order to ensure the determination of the error correction model, it is necessary for the coefficient sign of the error correction variable to be negative and significant.

Table 5. Error Correction Model Results

\begin{tabular}{|c|c|c|c|c|}
\hline Variable & Coefficient & Std. Error & t-Statistic & Prob. \\
\hline $\mathrm{D}(\mathrm{DCPI}(-1))$ & 0.144573 & 0.109880 & 1.315731 & 0.2002 \\
\hline $\mathrm{D}(\mathrm{DEF})$ & 3.760422 & 0.924493 & 4.067552 & 0.0004 \\
\hline $\mathrm{D}(\mathrm{DM} 2)$ & 0.634562 & 0.374699 & 1.693527 & 0.1028 \\
\hline CointEq(-1)* & -1.148142 & 0.184365 & -6.227559 & 0.0000 \\
\hline
\end{tabular}

The error correction coefficient estimated within the framework of the error correction model is statistically significant and contains a negative sign. This finding demonstrates that the short-term imbalances which occurred in the model have been eliminated in the long term. Furthermore, according to the data obtained from this table, it is observed that the ratio of budget deficits to GDP has an impact on inflation.

\section{CONCLUSION}

Maintaining the stability of the general price levels is one of the main macroeconomic targets of developing countries. Monetary and fiscal policies implemented by countries have an important role in ensuring price stability. Previous studies in the literature have not reached a consensus on the effectiveness of these policy instruments and suggested different views. It is necessary to determine which policies should be implemented to prevent inflation. In Turkish economy, it is important to properly determine which factors affect inflation, in order to ensure the effectiveness of preventive policies that would be implemented.

The increase in money supply has a direct effect on the general price levels and an independent central bank is the most important factor in ensuring the price stability according to the monetarist approach. In the framework of the FTPL approach, also called the fiscal approach, the determinant role of fiscal policies on the general level of prices has been emphasized. Accordingly, the main determinant of the price levels is not the amount of money, but the budget constraint linking the public debt stock with the budget balance which plays a decisive role.

In this study, the relationship between inflation, budget deficit and money supply in Turkey for the period 1980-2017, has been investigated by using Pesaran, Shin and Smith (2001)'s bounds testing approach. According to the results of ARDL model, budget deficit has a positive and significant effect on inflation in both long and short term. All findings obtained from the analysis show that budget deficits affect inflation for the selected term in Turkey and could support of the fiscal theory of price levels in long term.

Budget deficits experienced in Turkey constitute inflationary effect. It should be taken into consideration that not only monetary policy but also fiscal discipline is important in the against inflation. Fiscal and monetary policies should be harmonized and structural reforms should be accelerated in order to reduce inflation and achieve the targeted inflation rates successfully. 


\section{REFERENCES}

ABDİOĞLU, Z. and TERZİ, H., (2009), Enflasyon ve Bütçe Açıkları İlişkisi: Tanzi ve Patinkin Etkisi, Atatürk Üniversitesi İktisadi ve İdari Bilimler Dergisi, 23(2), 195-211.

ALTINTAŞ, H, ÇETINKAYA, H. and TABAN, S., (2008), Türkiye'de Bütçe Açığı, Parasal Büyüme ve Enflasyon Arasındaki İlişkinin Ekonometrik Analizi: 1992-2006, Anadolu Üniversitesi Sosyal Bilimler Dergisi, 8(2), 185-208.

AKEL, V. and GAZEL, S., (2014), Döviz Kurları ile BIST Sanayi Endeksi Arasındaki Eşbütünleşme İlişkisi: Bir ARDL Sınır Testi Yaklaşımı, Erciyes Üniversitesi İktisadi ve Iddari Bilimler Fakültesi Dergisi, 44, 23-41.

BAKARE, İ. A. O., ADESANYA, O.A. and BOLARINWA, S.A., (2014), Empirical Investigation Between Budget Deficit, Inflation and Money Supply in Nigeria, European Journal of Business and Social Sciences, 2(12), 120-134.

BEDİR, S. and DİKMEN, A.T., (2014), Bütçe Açı̆̆ı ve Enflasyon: Türkiye İçin Bir Sınır Testi Yaklaşımı, International Conference on Eurasian Economies 2014, 1-9.

CATAO, A.V. and TERRONES, M.E., (2005), Fiscal Deficits and Inflation, Journal of Monetary Economics, 52(3), 529-554.

CHAUDHARY, M. A. S. and PARAI, A. K., (1991), Budget Deficit and Inflation: The Peruvian Experience, Applied Economics, 23(6), 1117-1121.

CHIMOBI, O.P. and IGWE, O.L., (2010), Budget Deficit, Money Supply and Inflation in Nigeria, European Journal of Economics, Finance and Administrative Sciences, 19, 52 60 .

DICKEY, D. and FULLER, W.A., (1981), Likelihood Ratio Statistics for Autoregressive Time Series with A Unit Root, Econometrica, 49(4), 1057-1072.

GUJARATI, D.N., (2006), Temel Ekonometri, İstanbul: Literatür Yayınc1lık.

HABIBULLAH, M.S., CHEAH, C. and BAHAROM, A.H., (2011), Budget Deficits and Inflation in Thirteen Asian Developing Countries, International Journal of Business and Social Science, 2(9), 192-204.

HOANG, K. V., (2014), Budget Deficit, Money Growth and Inflation: Empirical Evidence From Vietnam, Munich Personal Repec Archive, National Graduate Institute for Policy Studies, Banking Academy, Paper No. 54488, 1-34.

HONROYIANNIS, G. and PAPAPETROU, E., (1997), Are Budget Deficits Inflationary? A Cointegration Approach, Applied Economics Letters, 4(8), 493 - 496.

KARRAS, G., (1994), Macroeconomic Effects of Budget Defecits: Further International Evidence, Journal of International Money and Finance, 13(2), 190-210.

KAYA, M.G., and ÖZ, E., (2016), Enflasyon, Bütçe Açı̆̆ı ve Para Arzı İlişkisinin Türkiye Ekonomisi Açısından Değerlendirilmesi: 1980-2014 Dönemi, Manisa Celal Bayar Üniversitesi İ.İ.B.F Yönetim ve Ekonomi, 23(3), 639-651.

KESBİÇ, C., BALDEMİ, E. and BAKIMLI E., (2005), Bütçe Açıkları İle Parasal Büyüme ve Enflasyon Arasındaki İlişki: Türkiye İçin Bir Model Denemesi, Atatürk Üniversitesi İktisadi ve İdari Bilimler Dergisi, 19 (1), 81-98.

KOYUNCU, F. T., (2014), Causality Network Between Budget Deficit, Money Supply and Inflation: An Application to Turkey, International Journal of Business and Social Science, 5-10(1), 225- 235. 
LEEPER, E., (1991), Equilibria Under 'Active' and 'Passive' Monetary and Fiscal Policies, Journal of Monetary Economics, 1991, 27(1), 129-147.

LOZANO, I., (2008), Budget Deficit, Money Growth and Inflation: Evidence From Colombia Case, Banco De La Republica, Borradores De Economia. No. 005127,1-25.

OKTAYER, A., (2010), Türkiye'de Bütçe Açı̆̆ı, Para Arzı ve Enflasyon İlişkisi, Maliye Dergisi, Sayı: 158, 431-447.

ÖZGÜN, D. B.,(2000), An Empirical Approach to Fiscal Deficits and Inflation: Evidence From Turkey,Hazine Müstesarlıg1, Ekonomik Arastırmalar Genel Müdürlügü: Ankara.

ÖZMEN, M. and KOÇAK, F. İ., (2012), Enflasyon Bütçe Açığı ve Para Arzı İlişkisinin ARDL Yaklaşımı ile Tahmini: Türkiye Örneği, Çukurova Üniversitesi İIBF Dergisi, 6(1), 119.

PESARAN, H, SHIN, Y and SMITH, R.J., (2001), Bound Testing Approaches to the Analysis of Long Run Relationships, Journal of Applied Econometrics, 16(3), 289-326.

PHILLIPS, P.C.B and PERON, P., (1988), Testing for a Unit Root in Time Series Regression, Biomètrika, 75(2), 336-346.

SARGENT, T.J. and WALLACE, N. (1981), Some Unpleasant Monetarist Arithmetic, Federal Reserve Bank of Minneapolis Quarterly Review, 5(3), 1-17.

SIMS, C., (1994), A Simple Model for Study of the Determination of the Price Level and the Interaction of Monetary and Fiscal Policy, Economic Theory, 4(3), 381-399.

ŞAHIN, İ. and KARANFIL, M., (2015), Türkiye Ekonomisinde 1980-2013 Dönemi Para Arzının Enflasyon Üzerindeki Etkisi, Business and Economics Research Journal, 6(4), 97-113.

TEKIN, K. A. and ÖZMEN, E., (2003), Budget Deficits, Money Growth and Inflation: The Turkish Evidence, Applied Economics, 35(5), 591-596.

UYGUR, E., (2001), Enflasyon, Para ve Mali Baskı: İktisat Politikasında Geri Kalmışlık, İktisat Isletme ve Finans, 16(189), 7-23.

WOODFORD, M., (2001), Fiscal Requirements for Price Stability, Journal of Money, Credit and Banking, 33(3), 669-728. 